OPEN ACCESS

Edited by:

Samantha Oester,

George Mason University,

United States

Reviewed by:

Edward Jeremy Hind-Ozan, Cardiff University, United Kingdom

Maria Louella Dolar

Silliman University, Philippines

*Correspondence:

Christopher D. Golden golden@hsph.harvard.edu

Specialty section:

This article was submitted to Marine Conservation and Sustainability,

a section of the journa Frontiers in Marine Science

Received: 15 March 2017 Accepted: 11 May 2017 Published: 29 May 2017

Citation: Golden $C D$, Seto KL, Dey MM, Chen OL, Gephart JA, Myers SS,

Smith $M$, Vaitla $B$ and Allison $E H$ (2017) Does Aquaculture Support the Needs of Nutritionally Vulnerable Nations?. Front. Mar. Sci. 4:159. doi: 10.3389/fmars.2017.00159

\section{Does Aquaculture Support the Needs of Nutritionally Vulnerable Nations?}

\author{
Christopher D. Golden ${ }^{1,2 *}$, Katherine L. Seto ${ }^{3}$, Madan M. Dey ${ }^{4}$, Oai L. Chen ${ }^{5}$, \\ Jessica A. Gephart ${ }^{6}$, Samuel S. Myers ${ }^{1,2}$, Matthew Smith ${ }^{1}$, Bapu Vaitla ${ }^{1}$ and \\ Edward H. Allison ${ }^{7}$
}

\begin{abstract}
${ }^{1}$ Department of Environmental Health, Harvard T.H. Chan School of Public Health, Boston, MA, United States, ${ }^{2}$ Harvard University Center for the Environment, Cambridge, MA, United States, ${ }^{3}$ Department of Environmental Science, Policy and Management, University of California, Berkeley, Berkeley, CA, United States, ${ }^{4}$ Department of Agriculture, Texas State University, San Marcos, TX, United States, ${ }^{5}$ Aquaculture Center, University of Arkansas, Pine Bluff, AR, United States, ${ }^{6}$ National Center for Socio-Ecological Synthesis (SESYNC), Annapolis, MD, United States, ${ }^{7}$ School of Marine and Environmental Affairs, University of Washington, Seattle, WA, United States
\end{abstract}

Aquaculture now supplies half of the fish consumed directly by humans. We evaluate whether aquaculture, given current patterns of production and distribution, supports the needs of poor and food-insecure populations throughout the world. We begin by identifying 41 seafood-reliant nutritionally vulnerable nations (NVNs), and ask whether aquaculture meets human nutritional demand directly via domestic production or trade, or indirectly via purchase of nutritionally rich dietary substitutes. We find that a limited number of NVNs have domestically farmed seafood, and of those, only specific aquaculture approaches (e.g., freshwater) in some locations have the potential to benefit nutritionally vulnerable populations. While assessment of aquaculture's direct contribution via trade is constrained by data limitations, we find that it is unlikely to contribute substantially to human nutrition in vulnerable groups, as most exported aquaculture consists of high-value species for international markets. We also determine that subpopulations who benefit from aquaculture profits are likely not the same subpopulations who are nutritionally vulnerable, and more research is needed to understand the impacts of aquaculture income gains. Finally, we discuss the relationship of aquaculture to existing trends in capture fisheries in NVNs, and suggest strategies to create lasting solutions to nutritional security, without exacerbating existing challenges in access to food and land resources.

Keywords: food security, micronutrient nutrition, seafood, trade deficit, sustainable food systems, planetary health

\section{INTRODUCTION}

For the first time in human history, farmed fish production has outpaced wild capture fisheries in seafood destined for human consumption (World Bank, 2014). Seafood is a critical component of our diets, comprising one-sixth of global animal source food consumption (FAO, 2014). With rapid human population growth, looming food insecurity (Godfray et al., 2010), and declining marine and freshwater fish stocks affecting food and nutrition security (Golden et al., 2016; McIntyre et al., 2016), aquaculture is a potential solution for cheaply and easily providing animal source foods to poor and food-insecure populations around the world (Kobayashi et al., 2015). 
Here, we ask whether aquaculture, given current patterns of production and distribution, supports the needs of such populations. This question has been asked before (i.e., Merino et al., 2012; Beveridge et al., 2013; Béné et al., 2016); however, our approach differs in that we begin by identifying nutritionally vulnerable nations (NVNs) and then determine whether aquaculture meets important nutritional needs in these settings. We find that, with exceptions, the evidence for aquaculture currently serving the needs of the nutritionally vulnerable is limited. However, there is enormous potential for aquaculture in supporting a burgeoning global population's dietary needs if policy reforms incentivize markets to deliver these resources equitably.

\section{The Role of Aquaculture in Nutritionally Vulnerable Nations}

Seafood is a nutritionally valuable food, rich in long-chain polyunsaturated fatty acids, iron, zinc, vitamin A, vitamin B12, and many other important micronutrients (Golden et al., 2016). In order to directly support the needs of those at risk of reduced access to seafood, aquaculture production must be accessible by nutritionally vulnerable populations either through domestic production or trade. For this to be true, at least one of the following conditions must be met:

(1) if domestic aquaculture production exists within a nutritionally vulnerable nation, products must remain primarily within the nation;

(2) if aquaculture production is focused in non-NVNs, then policies and/or market mechanisms must direct the flow of aquaculture products to NVNs.

Further, in order for aquaculture to indirectly support the needs of those at risk, if aquaculture production within NVNs is largely exported, income from the sale of aquaculture production must enable these nations to purchase nutritionally rich dietary substitutes. We define national vulnerability to nutritional deficiencies driven by inadequate intake of seafood as being characterized by two factors: risk and dependency (Golden et al., 2016). We define risk as the population of a country having its overall dietary nutrient supply within $2 \mathrm{x}$ the estimated average requirement (EAR) for iron, zinc, or vitamin $A^{1}$. We define dependency as a population's fish-derived nutrient supply comprising $>10 \%$ with respect to vitamin $\mathrm{A}$ or zinc or $>5 \%$ with respect to iron ${ }^{2}$. We also characterize nations vulnerable to inadequate supply of vitamin B12 or fatty acids by the proportion of seafood in their total animal source food supply, following

\footnotetext{
1 EAR is defined as the value at which $50 \%$ of the population is meeting its requirement. $2 \mathrm{x}$ EAR is chosen so that a sizeable portion of the population is still at risk of deficiency without requiring an alarmingly high percentage of $50 \%$ deficiency before raising concern. Furthermore, our nutritional assessment relies on nutrient supplies rather than nutrient intakes, which are assumed to represent an overestimate of true intakes.

${ }^{2}$ A lower threshold for vulnerability was used for iron because heme iron (a component of fish and other meat, but not vegetal, sources) is easily absorbed and therefore physiologically valuable in the diet.
}

methods in Golden et al. (2016). Based on these thresholds, we identified 41 seafood-based NVNs (Table 1$)^{3}$.

To assess the criterion by which aquaculture may have direct contribution to NVNs, we use the FAO global commodities production and trade database provided by FishStat) (FAO, 2016a) for statistics on annual production, imports and exports of fisheries commodities (for details, please see Supplementary Information). In the 41 nations most nutritionally vulnerable to reduced seafood access, a majority of these nations (26 of 41) have little or no aquaculture production (Figure 1). Of the remaining 15 nations that do have domestic aquaculture production, five nations have export-oriented aquaculture, meaning more than $50 \%$ of production by volume goes to international markets. By this assessment, 10 seafoodbased NVNs have domestic-oriented aquaculture production (Figure 1): Bangladesh, China, Cote d'Ivoire, Ghana, Indonesia, Republic of Korea, Laos, Malaysia, Philippines, and Sri Lanka. These nations represent a diverse array of aquaculture species and approaches, with mixed effectiveness in conferring farmed seafood to nutritionally vulnerable populations. In some cases, aquaculture is effectively retained for domestic food security; for example, carp- and tilapia-based aquaculture in Bangladesh, Indonesia, Laos, Philippines, and Sri Lanka are largely for domestic consumption (Bush and Kosy, 2007; Dey et al., 2008), and aquaculture approaches in nations such as Bangladesh have real potential for providing animal protein to poorer households (Dey et al., 2010; Toufique and Belton, 2014). In contrast, farmed species in nations such as Cote d'Ivoire and Ghana are often marketed to the emergent urban middle classes (Paclibare, 2005; Sanogo, 2006). Of note, having a domesticoriented aquaculture production system does not necessarily mean that nutritionally vulnerable subpopulations have access to or consume these aquaculture products. Moreover, even when aquaculture is consumed domestically by those in need, the biomass of wild capture fish can be compensated for but the nutritional shortfall still exists (Bogard et al., 2017).

In addition to domestic production, aquaculture may directly benefit NVNs through the import of non-domestically produced farmed seafood. However, assessing aquaculture's contribution to NVN imports is a difficult task. Since international trade statistics do not currently distinguish between wild caught and aquaculture products, precise estimates of aquaculture imports are not possible (FAO, 2016b). However, to determine whether the NVNs identified here were trading their seafood with other NVNs or with non-NVNs, we obtained 2014 data on both exports reported by any NVN as well as imports any country reported receiving from that NVN. Since separate estimates for capture and aquaculture were not available, we used total seafood trade (United Nations, 2014a), and found that generally less than $20 \%$ of exports were destined to other NVNs (Figure 1; Table 1). Since these data include both capture and aquaculture production, exports represent the upper limit of aquaculture trade reported between NVNs (Table 1). Therefore, while a complete picture of aquaculture imports to NVNs is not currently possible, only a

\footnotetext{
${ }^{3}$ We limit ourselves to considering developing nations, as classified by the United Nations (United Nations, 2014b).
} 
TABLE 1 | Total aquaculture production, aquaculture exports, total seafood exports, and percent of exports directed to nutritionally vulnerable nations (NVNs) from each NVN.

\begin{tabular}{|c|c|c|c|c|}
\hline Country & $\begin{array}{l}\text { Total aquaculture } \\
\text { production }(t)\end{array}$ & $\begin{array}{c}\text { Share of exports in aquaculture } \\
\text { production }(\%)\end{array}$ & $\begin{array}{l}\text { Total seafood } \\
\text { exports ( } 10^{6} \text { USD) }\end{array}$ & $\begin{array}{l}\text { NVN seafood exports } \\
\text { (\% total exports) }\end{array}$ \\
\hline Antigua and Barbuda [1] & 0.0 & 0.0 & 0.6 & 0.0 \\
\hline Bahamas [1] & 0.0 & 0.0 & 88.1 & 1.9 \\
\hline Bangladesh [1] & $1,523,759.0$ & 3.1 & 686.1 & 11.9 \\
\hline Barbados [1] & 10.5 & 53.3 & 1.8 & 0.2 \\
\hline Belize [1] & $5,102.0$ & 95.4 & 91.1 & 18.1 \\
\hline Benin [2] & 400.0 & 0.0 & 1.0 & 2.6 \\
\hline Brunei Darussalam [2] & 530.0 & 7.8 & 5.3 & 33.7 \\
\hline Cabo Verde [2] & 0.0 & 0.0 & 58.6 & 3.7 \\
\hline Chile [2] & $954,845.0$ & 88.2 & $5,746.3$ & 8.2 \\
\hline China [1] & $38,621,269.2$ & 7.4 & $14,837.7$ & 24.7 \\
\hline Congo republic of [2] & 68.0 & 0.0 & 2.0 & 2.0 \\
\hline Cote d'Ivoire [1] & $3,394.0$ & 0.0 & 11.3 & 7.2 \\
\hline Fiji [1] & 186.0 & 0.0 & 184.9 & 29.4 \\
\hline French Polynesia [2] & 61.2 & 1.2 & 15.2 & 0.8 \\
\hline Gambia [1] & 33.0 & 0.0 & 6.4 & 5.9 \\
\hline Ghana [1] & $19,092.0$ & 0.0 & 46.6 & 9.9 \\
\hline Grenada [1] & 0.0 & 0.0 & 7.7 & 2.5 \\
\hline Guinea [1] & 200.0 & 2.7 & 29.5 & 75.2 \\
\hline Guinea-Bissau [2] & 0.0 & 0.0 & 17.3 & 7.7 \\
\hline Guyana [2] & 263.1 & 17.9 & 101.9 & 9.3 \\
\hline Indonesia [2] & $2,718,421.1$ & 6.9 & $3,520.6$ & 19.5 \\
\hline Lao people's democratic republic [2] & $95,600.0$ & 0.0 & 0.0 & 95.5 \\
\hline Republic of Korea [2] & $507,052.0$ & 19.2 & $1,500.1$ & 25.7 \\
\hline Libya [1] & 10.0 & 0.0 & 15.6 & 23.3 \\
\hline Madagascar [2] & $8,845.0$ & 66.6 & 142.3 & 18.6 \\
\hline Malaysia [1] & $287,242.5$ & 27.8 & 713.3 & 18.4 \\
\hline Maldives [1] & 0.0 & 0.0 & 191.5 & 30.1 \\
\hline Mauritania [2] & 0.0 & 0.0 & 923.1 & 28.3 \\
\hline Mauritius [1] & 537.3 & 0.0 & 142.5 & 16.0 \\
\hline Mozambique [2] & 796.0 & 33.1 & 81.4 & 13.5 \\
\hline Peru [2] & $92,206.5$ & 69.3 & 917.7 & 16.2 \\
\hline Philippines [1] & $767,287.0$ & 2.7 & 691.8 & 20.4 \\
\hline Saint Lucia [2] & 10.9 & 0.0 & 0.2 & 0.5 \\
\hline Saint Vincent and the Grenadines [2] & 0.0 & 0.0 & 1.6 & 66.4 \\
\hline Senegal [2] & 334.6 & 23.1 & 514.3 & 30.3 \\
\hline Sri Lanka [1] & $11,910.9$ & 11.2 & 292.8 & 5.5 \\
\hline Suriname [2] & 209.2 & 45.5 & 96.7 & 5.8 \\
\hline Thailand [1] & $1,201,455.4$ & 59.6 & $2,435.5$ & 18.8 \\
\hline Trinidad and Tobago [2] & 19.7 & 61.2 & 66.6 & 9.3 \\
\hline United Arab Emirates [1] & 415.0 & 68.4 & 243.3 & 10.4 \\
\hline Yemen [1] & 150.0 & 58.1 & 233.9 & 7.3 \\
\hline
\end{tabular}

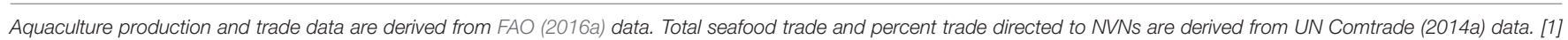
Denotes general trade data while [2] Denotes special export within FishStat. Details for these calculations are provided in the SI section.

small portion of aquaculture exported by NVNs remains available to nutritionally vulnerable populations. Further, considering the fact that $73 \%$ of world seafood imports are destined for developed nations, and aquaculture products are disproportionately highvalue exports destined for international markets, the substantial contribution to NVNs via imports appears unlikely (FAO, 2007;
Asche et al., 2015b). FAO further states that while aquaculture may represent an important component of food security, it is likely through consumption of low-value domestic species rather than import (Smith et al., 2010; FAO, 2016b).

In addition to the direct means by which aquaculture may support the needs of those most at risk, aquaculture products may 


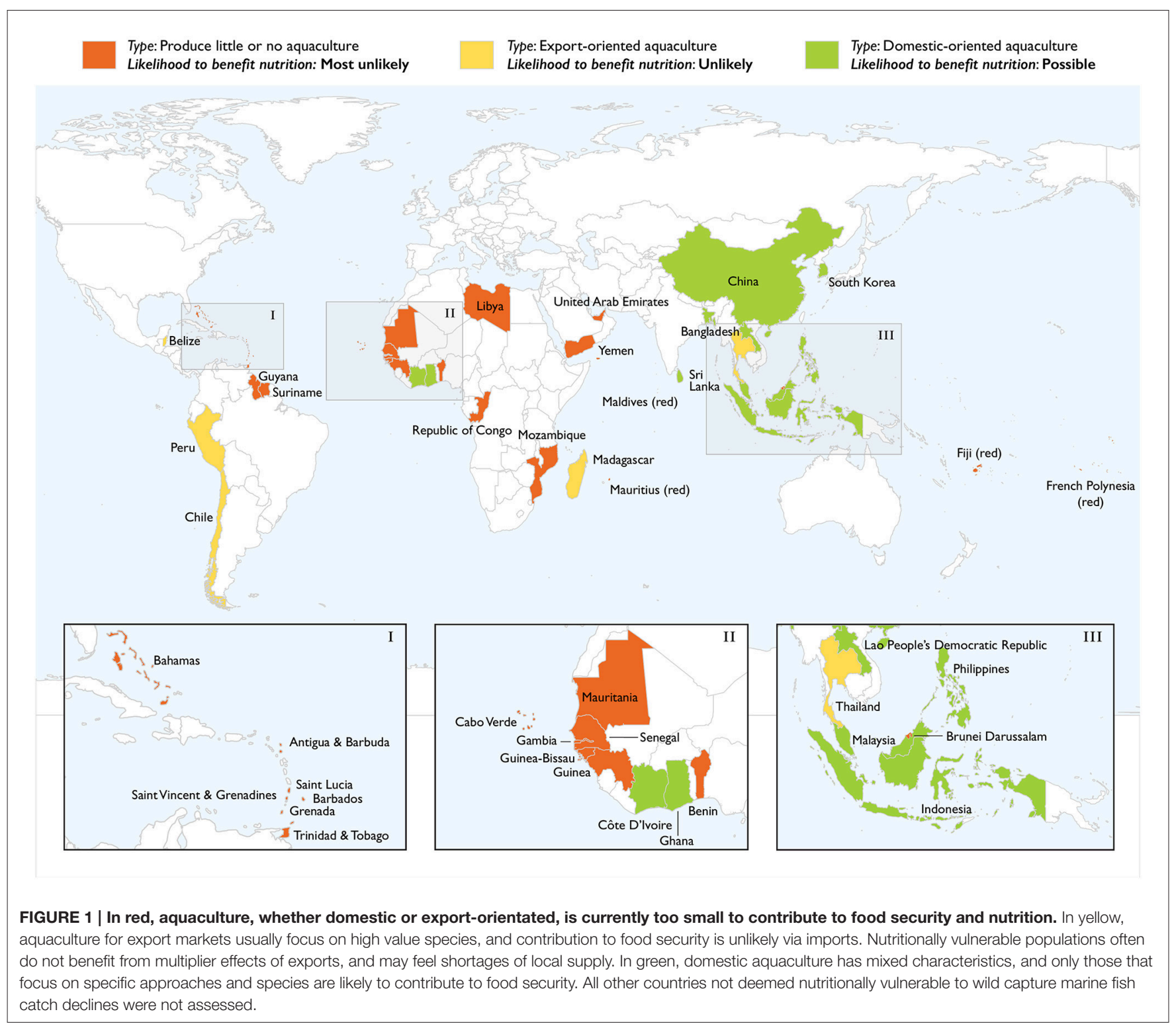

also indirectly benefit NVNs through the purchase of nutrientrich alternative foods with the income generated by the trade of domestic aquaculture products (Asche et al., 2015a). Classical theory of international trade and comparative advantage states there are welfare gains for both nations, in aggregate, when they open to trade. However, this theory does not assume equivalent gains in kind, an especially important consideration in the trade of nutrient-rich food products, and there are likely winners and losers from a nutritional standpoint in the transition to export-oriented fisheries production. Key questions with respect to this transition include: (1) who is losing access to seafood as a food source? (2) who is gaining income as a result of seafood exports? and (3) and what food products are being purchased with this increased income? It is likely that poor subsistence or artisanal fishermen will not receive the monetary benefits of national-level exports and may well feel the loss of locally available seafood supply (Béné et al., 2010). Even if these fishermen and those they support are benefiting from the multiplier effects of income gains through export/trade, they may not be purchasing foods of nutritional equivalence to seafood. These topics represent important future research directions.

\section{Challenges and Opportunities in Providing for Those at Risk}

An additional factor to consider is the relationship of aquaculture to existing trends in capture fisheries in NVNs. To understand how these trends interact with, and may be supplemented by, aquaculture, we considered the role of aquaculture in the 12 NVNs identified here as having export-oriented capture fisheries [Cabo Verde, Chile, Fiji, Guinea-Bissau, Guyana, Mauritania, Mauritius, Peru, Suriname, Thailand, United Arab 
Emirates, and Yemen]. Of the twelve, nine have limited or no aquaculture production at all, meaning that aquaculture does not presently compensate for what is lost from fisheries exports. The remaining three nations are Thailand, Peru and Chile. Thailand exports $95 \%$ of its fisheries production and $61 \%$ of its aquaculture production, totaling nearly four times the amount conserved for domestic consumption; therefore, Thai aquaculture is likely unable to compensate for the fish lost to export. Similarly, Chile's fisheries exports are nearly 16 times the national production volume of aquaculture conserved for domestic use, and Peru's exports total nearly 200 times the national aquaculture production conserved for domestic use. While this analysis does not account for potential extenuating factors (e.g., import and re-export of capture fisheries products), the emerging trend suggests that within the NVNs with export oriented capture fisheries, aquaculture is more likely to be integrated into export markets than it is to act as a nutritional substitute for local populations. Furthermore, this trend of seafood trade globalization is expected to continue in light of growing populations, increasing animal-source food demand, and shifts in production potential (Gephart and Pace, 2015).

In determining the importance of aquaculture to the overall global food system, it is important to understand the energy and resources directed from wild capture fisheries to aquaculture production. Yet straightforward analyses of trade-offs between aquaculture inputs and human consumption are confounded by rapid changes in aquaculture technologies and the rate of development in the sector. While previous analyses suggested that aquaculture growth may redirect nutritious capture fish resources away from nutritionally vulnerable consumers and toward aquaculture inputs (e.g., Naylor et al., 2000; Cashion et al., 2017), this relationship relies heavily on factors such as consumer acceptance, fish to non-fish ratios in aquaculture feeds, overall aquaculture production volume, environmental shocks, speciesspecific trends in feed, and global market dynamics (Naylor et al., 2009; Merino et al., 2012; Fréon et al., 2013; Troell et al., 2014). The environmental impacts of aquaculture will not be limited to wild capture fisheries. Aquaculture development often requires the enclosure of the coastal and riparian commons, which can displace users of these systems, notably in mangrove forest systems and on floodplains (Beitl, 2011; Sultana, 2012). Appropriate oversight to minimize environmental damage must be considered so as to limit the pollution and habitat destruction often connected to aquaculture production systems (Ottinger et al., 2016). While recent studies suggest aquaculture growth and capture fisheries sustainability may not represent a zero-sum game, the trade-offs for nutritionally vulnerable populations are as yet unclear (Naylor et al., 2009).

\section{CONCLUSIONS}

Despite significant challenges and uncertainties, there are ways in which aquaculture may improve access to seafood by nutritionally vulnerable populations. For example, despite the general lack of research on how purchasing power, market access, and dietary preferences affect consumption of aquaculture products by nutritionally vulnerable people (Kawarazuka and Béné, 2010; Béné et al., 2016), a few studies have found that some commercial aquaculture systems have led to price reductions in seafood products, and in turn, increased seafood consumption by the poor (Toufique and Belton, 2014; Troell et al., 2014). Furthermore, certain types of aquaculture industries have been shown to improve the livelihoods of economically disadvantaged people via development benefits (Dey et al., 2013; Little et al., 2016a). For example, semi-intensive freshwater aquaculture, with its low price (relative to marine capture seafood) and limited international markets, has become an increasingly important source of animal protein in some developing nations in Asia, with particular significance for medium and low-income populations (Murshed-e-Jahan and Pemsl, 2011; Diana, 2012; Pomeroy et al., 2014). Seasonal aquaculture and rice-fish culture are also important sources of protein and micronutrients for many of the world's poor (Fiedler et al., 2016; Haque and Dey, 2017). Although data are limited, there remains a tremendous amount of hope that aquaculture production can provide economic and nutritional support to the poor in the future (Beveridge et al., 2013; Little et al., 2016b).

The potential of aquaculture interventions to create lasting solutions to nutritional security, without exacerbating existing inequities in access to food and land resources, relies on development programs to take into account the socio-cultural dynamics of local food systems (Morgan et al., 2016). Strategies to achieve this might include:

(i) Investment in infrastructure to facilitate domestic and regional processing and trade in farmed seafood. Much development assistance in the fisheries and aquaculture sector has been directed toward supporting engagement in global value chains, neglecting the importance of domestic and regional value chains as potential markets for producers, and as sources of nutrition for low income rural and urban consumers (Béné et al., 2010).

(ii) Promoting research and extension mechanisms that support production of nutritious, lower-cost farmed fish and shellfish. Organizations that have historically done global public goods research in the sector, like the WorldFish Center (Ponzoni et al., 2011) and the Network of Aquaculture Centers of Asia (De Silva and Davy, 2010), remain valuable in ensuring research and development support to reach resource-poor farmers. This focus often includes species, production systems and markets that may be neglected when all sector development is left to the private sector.

(iii) Supporting land, water and sea tenure arrangements (FAO, 2012) that enable a range of producers to engage in the sector, including the landless poor who may be able to access waterways (e.g., Adivasi Bangladesh; Pant et al., 2014), communities or cooperatives that can organize to meet local demand (e.g., Cambodia, Lao; Phomsouvanh et al., 2015) and contract-farming arrangements (e.g., India; Umesh et al., 2010) that can compete with private firms in terms of scale of production and access to input and output markets. 
(iv) Encouraging policy development in the sector that considers the potential for mixed-intensity systems, ranging from technology-intensive recirculating (closed) systems, to low-input semi-extensive systems, such as shellfish beds and fish ponds (Diana, 2012).

(v) Incorporating the experience of agriculture, where productivist models are giving way to diverse policies that support conservation agriculture, peri-urban and urban agriculture, diversified rural livelihoods, and "nutrition-sensitive agriculture" (Pinstrup-Andersen, 2012).

With these systems in place, it will also be necessary to create policy and economic structures that facilitate the flow of affordable aquaculture products to those who are nutritionally vulnerable. With aquaculture and wild capture fisheries products being roughly nutritionally comparable, we must also ensure improvements in fisheries management and marine conservation schemes that will facilitate equitable delivery of seafood to nutritionally vulnerable populations. In essence, we are suggesting a move toward nutrition-sensitive aquaculture and fisheries policies.

\section{AUTHOR CONTRIBUTIONS}

CG, KS, JG, BV, and EA designed the study with intellectual contribution from all authors. CG, JG, OC, and BV conducted

\section{REFERENCES}

Asche, F., Bellemare, M. F., Roheim, C., Smith, M. D., and Tveteras, S. (2015a). Fair enough? Food security and the international trade of seafood. World Dev. 67, 151-160. doi: 10.1016/j.worlddev.2014.10.013

Asche, F., Dahl, R. E., and Steen, M. (2015b). Price volatility in seafood markets: farmed vs. Wild Fish. Aquac. Econ. Manage. 19, 316-335. doi: 10.1080/13657305.2015.1057879

Beitl, C. M. (2011). Cockles in custody: the role of common property arrangements in the ecological sustainability of mangrove Fisheries on the Ecuadorian Coast. Int. J. Commons 5, 485. doi: 10.18352/ijc.285

Béné, C., Arthur, R., Norbury, H., Allison, E. H., Beveridge, M., Bush, S., et al. (2016). Contribution of fisheries and aquaculture to food security and poverty reduction: assessing the current evidence. World Dev. 79, 177-196. doi: 10.1016/j.worlddev.2015.11.007

Béné, C., Lawton, R., and Allison, E. H. (2010). Trade matters in the fight against poverty: narratives, perceptions, and (Lack of) evidence in the case of fish trade in Africa. World Dev. 38, 933-954. doi: 10.1016/j.worlddev.2009.12.010

Beveridge, M. C. M., Thilsted, S. H., Phillips, M. J., Metian, M., Troell, M., and Hall, S. J. (2013). Meeting the food and nutrition needs of the poor: the role of fish and the opportunities and challenges emerging from the rise of aquaculture. J. Fish Biol. 83, 1067-1084. doi: 10.1111/jfb.12187

Bogard, J. R., Farook, S., Marks, G. C., Waid, J., Belton, B., Ali, M., et al. (2017). Higher fish but lower micronutrient intakes: temporal changes in fish consumption from capture fisheries and aquaculture in Bangladesh. PLoS ONE 12:e0175098. doi: 10.1371/journal.pone.0175098

Bush, S. R., Belton, B., Hall, D., Vandergeest, P., Murray, F. J., Ponte, S., et al. (2013). Global food supply. Certify sustainable aquaculture? Science 341, 1067-1068. doi: $10.1126 /$ science. 1237314

Bush, S. R., and Kosy, S. (2007). Geographical Distribution of investment in small-scale rural fish ponds. Aquac. Econ. Manage. 11, 285-311. doi: 10.1080/13657300701530308

Cashion, T., Le Manach, F., Zeller, D., and Pauly, D. (2017). Most fish destined for fishmeal production are food-grade fish. Fish Fish. doi: 10.1111/faf.12209. [Epub ahead of print]. the analysis. CG and KS drafted the manuscript. All authors significantly contributed to revising and improving the manuscript.

\section{FUNDING}

This work was supported by the National Socio-Environmental Synthesis Center (SESYNC) under funding received from the National Science Foundation DBI-1052875 (CG, EA, JG), the Wellcome Trust Our Planet, Our Health [Grant number: 106864MA] (CG, EA, SM), and the National Science Foundation GRF (KS).

\section{ACKNOWLEDGMENTS}

We would like to thank the International Marine Conservation Congress for bringing together our team and inspiring some of these ideas, and Julia Van Horn for assistance with design and layout.

\section{SUPPLEMENTARY MATERIAL}

The Supplementary Material for this article can be found online at: http://journal.frontiersin.org/article/10.3389/fmars. 2017.00159/full\#supplementary-material

Clarke, S. (2009). Understanding China's Fish Trade and Traceability. Kuching: TRAFFIC East Asia.

De Silva, S. S., and Davy, F. B. (eds.). (2010). Success Stories in Asian Aquaculture. Dordrecht: Springer Netherlands.

Dey, M. M., Alam, M. F., and Bose, M. L. (2010). Demand for aquaculture development: perspectives from Bangladesh for improved planning. Rev. Aquac. 2, 16-32. doi: 10.1111/j.1753-5131.2010. 01020.x

Dey, M. M., Briones, R. M., Garcia, Y. T., Nissapa, A., Rodriguez, U. P., Talukder, R. K., et al. (2008). Strategies and Options for Increasing and Sustaining Fisheries and Aquaculture Production to Benefit Poorer Households in Asia. Penang: WorldFish.

Dey, M. M., Spielman, D. J., Haque, A. B. M. M., Rahman, M. S., and ValmonteSantos, R. (2013). Change and diversity in smallholder rice-fish systems: recent evidence and policy lessons from Bangladesh. Food Policy 43, 108-117. doi: 10.1016/j.foodpol.2013.08.011

Diana, J. S. (2012). Is lower intensity aquaculture a valuable means of producing food? An evaluation of its effects on near-shore and inland waters. Rev. Aquac. 4, 234-245. doi: 10.1111/j.1753-5131.2012. 01079.x

Errighi, L., Mamic, I., and Krogh-Poulsen, B. (2016). Global Supply Chains: Insights into the Thai Seafood Sector. Bangkok: International Labour Organization.

EUMOFA (2013). Data management, Annex 8: Conversion Factors by CN-8 Codes from 2007 to 2012. Brussels and European Union.

European Commission (2011). The EU System for Fisheries Controls Conversion Factors. Available online at: http://ec.europa.eu/fisheries/cfp/control/ conversion_factors/table 01.pdf

FAO (2007). FAO FishCode- STF/CECAF/FCWC Subregional Workshop on the Improvement of Fishery Information and Data Collection Systems in the West Central Gulf of Guinea Region. Accra: FAO.

FAO (2012). Voluntary Guidelines on the Responsible Governance of Tenure of Land, Fisheries and Forests in the Context of National Food Security. Rome: FAO. FAO (2014). FAO Yearbook - Fishery and Aquaculture Statistics 2012. Rome: FAO. FAO (2015). CWP Handbook of Fishery Statistical Standards. FAO. Available online at: www.fao.org/fishery/cwp/search/en 
FAO (2016a). FishStat $J$ Database. Available online at: http://www.fao.org/fishery/statistics/software/fishstatj/en

FAO (2016b). The State of World Fisheries and Aquaculture 2016. Rome: FAO.

Fiedler, J. L., Lividini, K., Drummond, E., and Thilsted, S. H. (2016). Strengthening the contribution of aquaculture to food and nutrition security: the potential of a vitamin A-rich, small fish in Bangladesh. Aquaculture 452, 291-303. doi: 10.1016/j.aquaculture.2015.11.004

Fréon, P., Sueiro, J. C., Iriarte, F., Miro Evar, O. F., Landa, Y., Mittaine, J.-F., et al. (2013). Harvesting for food versus feed: a review of Peruvian fisheries in a global context. Rev. Fish Biol. Fish. 24, 381-398. doi: 10.1007/s11160-013-9336-4

Gephart, J. A., and Pace, M. L. (2015). Structure and evolution of the global seafood trade network. Environ. Res. Lett. 10, 125014-125012. doi: 10.1088/1748-9326/10/12/125014

Godfray, H. C. J., Beddington, J. R., Crute, I. R., Haddad, L., Lawrence, D., Muir, J. F., et al. (2010). Food security: the challenge of feeding 9 billion people. Science 327, 812-818. doi: 10.1126/science.1185383

Golden, C. D., Allison, E. H., Cheung, W. W. L., Dey, M. M., Halpern, B. S., McCauley, D. J., et al. (2016). Nutrition: fall in fish catch threatens human health. Nature 534, 317-320. doi: 10.1038/534317a

HHaque, A. B. M. M., and Dey, M. M. (2017). Impact of community-based fish culture in seasonal floodplains on income, food security and employment in Bangladesh. Food Sec. 9, 25-38. doi: 10.1007/s12571-016-0629-z

Hasan, M. R., Halwart, M., and FAO (2009). Fish as Feed Inputs for Aquaculture: Practices, Sustainability and Implications. Rome: Food and Agriculture Organization of the United Nations.

Kawarazuka, N., and Béné, C. (2010). Linking small-scale fisheries and aquaculture to household nutritional security: an overview. Food Security 2, 343-357. doi: 10.1007/s12571-010-0079-y

Kobayashi, M., Msangi, S., Batka, M., Vannuccini, S., Dey, M. M., and Anderson, J. L. (2015). Fish to 2030: the role and opportunity for aquaculture. Aquac. Econ. Manage. 19, 282-300. doi: 10.1080/13657305.2015.994240

Little, D. C., Newton, R. W., and Beveridge, M. C. M. (2016a). Aquaculture: a rapidly growing and significant source of sustainable food? Status, transitions and potential. Proc. Nutr. Soc. 75, 274-286. doi: 10.1017/S0029665116000665

Little, D. C., Newton, R. W., and Beveridge, M. C. M. (2016b). Aquaculture: a rapidly growing and significant source of sustainable food? Status, transitions and potential. Proc. Nutr. Soc. 75, 274-286. doi: 10.1017/S0029665116000665

McIntyre, P. B., Reidy Liermann, C. A., and Revenga, C. (2016). Linking freshwater fishery management to global food security and biodiversity conservation. Proc. Natl. Acad. Sci. U.S.A. 113, 201521540-201521546. doi: 10.1073/pnas.1521540113

Merino, G., Barange, M., Blanchard, J. L., Harle, J., Holmes, R., Allen, I., et al. (2012). Can marine fisheries and aquaculture meet fish demand from a growing human population in a changing climate? 22, 795-806. doi:10.1016/j.gloenvcha.2012.03.003

Morgan, M., Terry, G., Rajaratnam, S., and Pant, J. (2016). Socio-cultural dynamics shaping the potential of aquaculture to deliver development outcomes. Rev. Aquac. doi: 10.1111/raq.12137. [Epub ahead of print].

Murshed-e-Jahan, K., and Pemsl, D. E. (2011). The impact of integrated aquaculture-agriculture on small-scale farm sustainability and farmers' livelihoods: experience from Bangladesh. Agric. Syst. 104, 392-402. doi: 10.1016/j.agsy.2011.01.003

Naylor, R. L., Goldburg, R. J., Primavera, J. H., Kautsky, N., Beveridge, M., Clay, J., et al. (2000). Effect of aquaculture on world fish supplies. Nature 405, 1017-1024. doi: $10.1038 / 35016500$

Naylor, R. L., Hardy, R. W., Bureau, D. P., Chiu, A., Elliott, M., Farrell, A. P., et al. (2009). Feeding aquaculture in an era of finite resources. Proc. Natl. Acad. Sci. U.S.A. 106, 15103-15110. doi: 10.1073/pnas.0905235106

Oceanic Developpement, Poseidon Aquatic Resources Management Ltd, and MegaPesca Ltd. (2005). The European Tuna Sector: Economic Situation, Prospects and Analysis of the Impact of the Liberalization of Trade. Concarneau.
Ottinger, M., Clauss, K., and Kuenzer, C. (2016). Aquaculture: relevance, distribution, impacts and spatial assessments - a review. Ocean Coast. Manag. 119, 244-266. doi: 10.1016/j.ocecoaman.2015.10.015

Paclibare, J. O. (2005). National Aquaculture Sector Overview: Philippines. Rome: FAO Fisheries and Aquaculture Department.

Pant, J., Barman, B. K., Murshed-e-Jahan, K., Belton, B., and Beveridge, M. (2014). Can aquaculture benefit the extreme poor? A case study of landless and socially marginalized Adivasi (ethnic) communities in Bangladesh. Aquaculture 418-419, 1-10. doi: 10.1016/j.aquaculture.2013.09.027

Phomsouvanh, A., Saphakdy, B., and De Silva, S. S. (2015). Production trends, monetary returns and benefit sharing protocols from the extensive aquaculture practice of culture-based fisheries in rural communities in Lao PDR. Aquaculture 439, 29-38. doi: 10.1016/j.aquaculture.2015.01.022

Pinstrup-Andersen, P. (2012). Can agriculture meet future nutrition challenges? Eur. J. Dev. Res. 25, 5-12. doi: 10.1057/ejdr.2012.44

Pomeroy, R., Dey, M. M., and Plesha, N. (2014). The social and economic impacts of semi-intensive aquaculture on biodiversity. Aquac. Econ. Manage. 18, 303-324. doi: 10.1080/13657305.2014.926467

Ponzoni, R. W., Nguyen, N. H., Khaw, H. L., Hamzah, A., Bakar, K. R. A., and Yee, H. Y. (2011). Genetic improvement of Nile tilapia (Oreochromis niloticus) with special reference to the work conducted by the WorldFish Center with the GIFT strain. Rev Aquac. 3, 27-41. doi: 10.1111/j.1753-5131.2010. 01041.x

Sanogo, M. (2006). National Aquaculture Sector Overview: Côte d'Ivoire. Rome: FAO Fisheries and Aquaculture Department.

Smith, M. D., Roheim, C. A., Crowder, L. B., Halpern, B. S., Turnipseed, M., Anderson, J. L., et al. (2010). Sustainability and global seafood. Science 327, 784-786. doi: 10.1126/science. 1185345

Sultana, P. (2012). Implications of floodplain aquaculture enclosure. J. Environ. Plann. Manage. 55, 1159-1174. doi: 10.1080/09640568.2011.637104

Tacon, A. G. J., Hasan, M. R., and Subasinghe, R. P. (2006). Use of Fishery Resources as Feed Inputs to Aquaculture Development. Rome: FAO.

Toufique, K. A., and Belton, B. (2014). Is aquaculture pro-poor? Empirical evidence of impacts on fish consumption in Bangladesh. World Dev. 64, 609-620. doi: 10.1016/j.worlddev.2014.06.035

Troell, M., Naylor, R. L., Metian, M., Beveridge, M., Tyedmers, P. H., Folke, C., et al. (2014). Does aquaculture add resilience to the global food system? Proc. Natl. Acad. Sci. U.S.A. 111, 13257-13263. doi: 10.1073/pnas.14040 67111

Umesh, N. R., Mohan, A. B. C., Ravibabu, G., Padiyar, P. A., Phillips, M. J., Mohan, C. V., et al. (2010). "Shrimp farmers in India: empowering small-scale farmers through a cluster-based approach," in Success Stories in Asian Aquaculture, eds S. S. De Silva and F. B. Davy (Dordrecht: Springer Netherlands), 41-66.

United Nations (2014a). UN Comtrade Database. Available online at: http:// comtrade.un.org/

United Nations (2014b). World Economic Situation and Prospects 2014. New York, NY: United Nations.

World Bank (2014). Fish to 2030: Prospects for Fisheries and Aquaculture. Washington, DC: World Bank.

Conflict of Interest Statement: The authors declare that the research was conducted in the absence of any commercial or financial relationships that could be construed as a potential conflict of interest.

Copyright $\odot 2017$ Golden, Seto, Dey, Chen, Gephart, Myers, Smith, Vaitla and Allison. This is an open-access article distributed under the terms of the Creative Commons Attribution License (CC BY). The use, distribution or reproduction in other forums is permitted, provided the original author(s) or licensor are credited and that the original publication in this journal is cited, in accordance with accepted academic practice. No use, distribution or reproduction is permitted which does not comply with these terms. 